\title{
MENUJU DESENTRALISASI KEBIJAKAN EKONOMI DALAM ISLAM: Pengalaman Dinasti 'Uśmaniyyah Abad 16-18 M dan Indonesia di Masa Orde Baru
}

\author{
Yuli Andriansyah \\ Program Studi Ekonomi Islam, FIAI, Universitas Islam Indonesia, Yogyakarta, \\ email: yuliandriansyah@uii.ac.id
}

\begin{abstract}
Abstrak
Artikel ini mengkaji model desentralisasi kebijakan ekonomi dalam perspekif Islam dengan menganalisa akar desentralisasi pada Alquran, hadits dan a ar sahabat serta pengalaman Dinasti ' $U$ māniyyah terutama pada abad 16-18M dan pada Indonesia di masa Orde Baru menerapkan kebijakan desentralisasi. Hasil kajian menunjukkan bahwa Islam memberikan peluang pengembangan desentralisasi meskipun model utama pemerintahan yang diakui bersifat sentralistik. Dinasti ' $U$ māniyyah yang memiliki wilayah luas menerapkan desentralisasi dengan kekuasaan lokal dipegang oleh pimpinan militer dengan sejumlah derajat kebebasan dalam pengaturan pendapatan di wilayahnya. Masa Orde Baru di Indonesia dimaksudkan untuk mewujudkan pemerintahan yang terdesentralisasi dengan pembangunan berbasis daerah. Namun mengingat keterbatasan daerah dalam aspek sumber pendapatan dan banyaknya pimpinan daerah berlatar belakang militer, semangat desentralisasi berubah menjadi sentralisasi demi alasan stabilitas ekonomi dan pertumbuhan ekonomi. Berdasarkan akar ajaran Islam dan pengalaman sejarah tersebut, desentralisasi dalam kerangka Islam dirumuskan sebagai sebuah pola pemerintahan yang bertujuan mencapai kemajuan ekonomi dan stabilitas politik secara seimbang dengan tetap mengindahkan tujuan syariah.
\end{abstract}

Kata kunci: desentralisasi, Dinasti 'U māniyyah, Orde Baru, ekonomi Islam

\begin{abstract}
This article describes a decentralized model of economic policy from Islamic perspective by analyzing root of decentralization in Holy Koran, prophetic sayings, and Shabbat's practices along with experiences of Ottoman Empire during 16-18 centuries and in Indonesia New Order Baru. The results suggest that Islam provide alternative to decentralization although its main idea of politics is centralized one. Ottoman Empire with its vast regions decided to implement decentralization with mostly military administrative in local power with different degrees of freedom in dealing with their financial matters. While in the Indonesian New Order, decentralization was aimed to establish local-based development. But due to local limitations along with military-based local leaders, decentralization turn to centralization for economic stability and growth. Based on the root of decentralization in Islam and experiences of Muslim societies, this article proposed a model of decentralized government in Islam with economic advancement and political stability as its main goals along with fulfillment of sharia purposes.
\end{abstract}

Keywords: decentralization, Ottoman Empire, New Order, Islamic economics 


\section{Pendahuluan}

Desentralisasi saat ini menjadi salah satu tren dari sistem politik dan ekonomi yang diadopsi banyak negara di dunia, termasuk negara-negara Islam atau berpenduduk mayoritas muslim. Desentralisasi dapat dimaknai sebagai: "the transfer of authority, responsibility, and resources-through deconcentration, delegation, or devolution-from the center to lower levels of administration" "atau "pemindahan kekuasaan, tanggung jawab, dan sumber daya melalui deconsentrasi, delegasi, atau devolusi dari pusat administrasi ke bagian di bawahnya". Secara internasional, desentralisasi seringkali dijadikan arahan di negara berkembang dalam rangka menciptakan penyesuaian struktural dengan tujuan akhir meningkatkan akses ke pasar, memperkuat demokrasi dan menciptakan tata kelola yang baik. ${ }^{2}$

Negara dengan wilayah yang luas, jumlah penduduk yang banyak, dan memiliki kebutuhan atau tuntutan nasional lainnya kerap menerapkan kebijakan desentralisasi, termasuk desentralisasi fiskal. Desentralisasi fiskal dapat dimaknai sebagai "an increase in taxing and/or spending responsibilities given to subnational jurisdictions" 3 atau peningkatan pada kewajiban pemungutan pajak dan pengeluarannya pada wilayah kekuasaan yang lebih kecil pada sebuah negara. Negara bagian, provinsi, kabupaten, distrik dan bentuk lainnya adalah bagian dari pembagian wilayah kekuasaan pada sebuah negara dalam rangka mengakomodasi desentralisasi fiskal ini. ${ }^{4}$

1 G. Shabbir Cheema dan Dennis A. Rondinelli, "From Government Decentralization to Decentralized Governance", dalam G. Shabbir Cheema dan Dennis A. Rondinelli (eds.), Decentralizing Governance: Emerging Concepts and Practices, (Washington, D.C.: Brookings Institution Press, 2007), hal. 1.

2 G. Shabbir Cheema dan Dennis A. Rondinelli, "From Government Decentralization ..., hal. 4.

${ }^{3}$ Vito Tanzi, "Pitfalls on the Road to Fiscal Decentralization", dalam Ehtisham Ahmad dan Vito Tanzi, Managing Fiscal Decentralization, (London, United Kingdom: Routledge, 2002), hal. 17-30.

${ }^{4}$ Ibid.
Desentralisasi fiskal dapat diwujdukan dalam bentuk negara federalis, maupun tetap dalam negara kesatuan. Sejumlah negara yang termasuk dalam kategori federalis adalah Argentina, Australia, Brazil, Canada, India, Nigeria, Rusia dan Amerika Serikat. Sedangkan sejumlah negara seperti China, Indonesia, Kolombia, Italia, Spanyol dan lainnya saat ini termasuk yang memasuki masa desentralisasi fiskal dengan beragam tingkatan kebebasan di level pemerintah daerahnya. Selain faktor luasnya wilayah, perkembangan politik dan tekanan publik juga dapat menjadi pemicu pelaksanaan desentralisasi fiskal yang lebih cepat. Terdapat sejumlah manfaat dalam desentralisasi fiskal berupa (a) sensitivitas pada perbedaan preferensi wilayah, (b) terbukanya preferensi berdasarkan mobilitas rumah tangga, (c) melindungi kepentingan generasi mendatang, dan (d) menghalangi perilaku mencari keuntungan secara sepihak oleh pemerintah. ${ }^{6}$ Adapun masalah yang dapat saja muncul dalam desentralisasi fiskal adalah berupa (a) alokasi sumber daya yang tidak optimal di antara berbagai daerah, (b) mengakibatkan kompetisi tidak sehat dalam pajak untuk faktor produksi yang mudah bergerak, (c) mengakibatkan perpindahan beban pajak antar daerah dan juga pemanfaatan barang publik, (d) distribusi pendapatn yang kurang optimal di dalam satu wilayah, (e) distribusi pendapatan yang kurang optimal di antara beberapa wilayah, (f) kurang optimalnya kebijakan stabilisasi, dan $(\mathrm{g})$ derajat desentralisasi fiskal yang optimal. $^{7}$

Meskipun banyak digunakan sebagai sistem dalam politik dan ekonomi di banyak negara, perhatian para peneliti terhadap desentralisasi dari perspektif Islam, masih sangat terbatas. Hal ini dapat dilihat dari minimnya kajian terkait masalah

\section{${ }^{5}$ Ibid.}

6 Dietmar Wellisch, Theory of Public Finance in a Federal State, (Cambridge: Cambridge University Press, 2004), hal. 14-17.

Dietmar Wellisch, Theory of Public Finance, hlm. 17-22. 
desentralisasi dengan mengaitkannya pada pengalaman umat Islam, menelusurinya dari ajaran Islam, maupun realisasinya dengan konteks kehidupan umat Islam saat ini. Alasan mengapa hal ini terjadi dapat ditelusuri dalam ajaran Islam tentang pentingnya persatuan sebagaimana tercermin dalam Q.S. Āli Imrān [3] ayat $103^{8}$. Ayat ini menurut penafsiran Ibnu Mas'ūd bermakna jamaah, yaitu perintah Allah SWT untuk bersatu dan menghindari perpecahan karena perpecahan menjadi sumber kehancuran dan persatuan menjadi awal bagi keberhasilan. ${ }^{9}$ Selain ayat ini di empat lain tempat dalam Alquran akar kata i'ta ama yang dikaitkan dengan Allah terulang dengan beragam bentuknya, yaitu pada Āli Imrān [3] ayat 101, An-Nisā' [4] ayat 146 dan 175, dan Al- ajj [22] ayat 78. Hal ini menandakan kuatnya dorongan untuk bersatu dalam ajaran Islam.

Selain memiliki fondasi yang kuat dalam ajaran Alquran, persatuan sebagai bentuk ideal dalam pemerintahan juga diperkuat dengan pandangan politik mayoritas di dunia Islam terutama Sunnī. AlMāwardī ${ }^{10}$ misalnya menegaskan posisi

8 Terjemahannya adalah: "Dan berpegangteguhlah kamu semuanya kepada tali (agama) Allah, dan janganlah kamu bercerai berai, dan ingatlah nikmat Allah kepadamu ketika kamu dahulu (masa jahiliyah) bermusuhan, lalu Allah mempersatukan hatimu, sehingga dengan karunia-Nya kamu menjadi bersaudara, sedangkan (ketika itu) kamu berada di tepi jurang neraka, lalu Allah menyelamatkan kamu dari sana. Demikianlah, Allah menerangkan ayat-ayat-Nya kepadamu, agar kamu mendapat petunjuk.", lihat Yayasan Penyelenggara Penerjemah Al-Qur'an, Al-Qur'an Al-Karim dan Terjemahnya Departemen Agama RI Edisi 2002, (Semarang: Toha Putra, 2002), hal.79.

${ }^{9}$ Abū Abd Allāh Mu ammad ibn A mad ibn Abū Bakr Al-Qur ub̄̄, Al-Jāmi' li A kām Al-Qur'an wa Al-Mubīnu li mā ta amanahu min As-Sunnah wa Āy Al-Furqān, Edisi Pertama, ditahqīq oleh 'Abd Allāh ibn Abd Al-Mu sin At-Turkī dan Mu ammad Ri wān 'Arsūqī, (Beirut: Al-Resalah Publishers, 2007), juz 5, hal. 240-241.

${ }^{10}$ Nama lengkapnya Abū al- asan 'Alī ibn Mu ammad ibn abīb al-Māwardī, atau Alboacen dalam sebutan Latin. Beliau lahir di Ba ra 364 H/974 $\mathrm{M}$ dan meninggal di Baghdad $450 \mathrm{H} / 1058 \mathrm{M}$. Lihat C. Brockelmann, "al-Māwardī, Abū 'l- asan Alī b. $\mathrm{Mu}$ ammad b. abīb," dalam C.E. Bosworth, E. van Donzel, B. Lewis, dan Ch. Pellat (eds.), The kekhalifahan sebagai kewajiban ilahiah dan bukan berasal dari pencapaian akal semata. Demi menjaga persatuan umat kala itu, ia bahkan menyetujui sahnya kepemimpinan seorang khalifah yang dikuasai oleh sejumlah kekuatan politik atau militer selama kekuatan dominan tersebut tidak bersifat destruktif dan separatis. ${ }^{11}$ Pandangan ini muncul demi mengakomodasi kondisi Dinasti Buwaihiyyah di akhir masa kekuasaan mereka yang kekuatan politiknya semakin tergerus oleh Dinasti Saljūq. Pola kepemimpinan akomodatif semacam ini menunjukkan penekanan yang besar terhadap kekuasaan yang terpusat dan stabil meskipun khalifah telah turun statusnya sebagai simbol pemersatu saja.

Pentingnya khalifah dalam mengelola kekuasaan demi menjaga persatuan ini kemudian diteguhkan dengan doktrin politik yang sangat terkenal: "60 tahun di bawah pimpinan yang jahat itu lebih baik daripada satu malam tanpa pemimpin." 12 Doktrin politik ini antara lain berasal dari pemahaman atas hadits Nabi Saw tentang pentingnya menegakkan add yang dianggap lebih baik dari anugerah berupa hujan selama empat puluh malam sebagaimana diriwayatkan Ibnu Mājah dalam Sunannya. ${ }^{13}$

Kecenderungan pada pemusatan kekuatan dalam Islam juga tercermin dalam pandangan politik Shakib Arslan di masa

Encyclopedia of Islam New Edition, (Leiden: E.J. Brill, 1991), Volume VI, hal. 869 dan Encyclopædia Britannica, "Māwardī, al-“, Encyclopeedia Britannica Ultimate Reference Suite, (Chicago: Encyclopædia Britannica, 2012).

${ }^{11}$ Ovamir Anjum, "al-A kām al-Sul ānīyah" dalam The [Oxford] Encyclopedia of Islam and Law, Oxford Islamic Studies Online, diakses dari http://www.oxfordislamicstudies.com/article/opr/t349/ e0001 pada 4 Mei 2013.

12 Syuhada Bahri, "Kepemimpinan Islam", dalam Buletin Al-Jazeera, Edisi 04/Th. 2/2010, diakses dari http://aljazeeraik2s.blogspot.com/2010/09/kepemimpinanislam.html 11 Maret 2011.

${ }^{13}$ Teks hadits 2537 terkait hal ini adalah [

حد من حدود الله، خيرمن مطر أربعين ليلة، في بلاد اله عز وجل ],

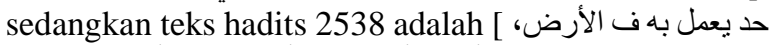
[خير لأهل الأرض من أن يمطروا أربعين صباحا. Lihat "Sunan Ibn Mājah", Mausū'ah Al-Hadi An-Nabaw̄̄, Al-I dār Ats-Tsānī. 
akhir kekuasaan Dinasti 'U māniyyah. Ia menilai bahwa tuntutan desentralisasi dan otonomi di berbagai wilayah yang dikuasai Dinasti 'U māniyyah sebagai bagian dari upaya meningkatkan pengaruh Eropa dan mengganggu kedaulatan Dinasti 'U māniyyah. Karenanya, ia menyebut mereka yang mendukung desentralisasi sebagai pembangkang dan pengkhianat. Tujuan pandangan ini dalah untuk menjaga kekuatan dan kendali kekuasaan di pusat pemerintahan Dinasti 'U māniyyah. ${ }^{14}$ Ia bahkan tidak tertarik pada pandangan politik Pan-Islam a la Jamaluddin Al-Afghani dan Muhammad Abduh. ${ }^{15}$ Hal ini menjadi salah satu penguat pandangan sentralisasi kekuasaan dalam Islam yang menekankan pentingnya pemerintah pusat sebagai pemersatu.

Apakah ini menandakan tidak adanya ruang bagi sistem desentralisasi dalam Islam? Artikel ini dimaksudkan antara lain untuk menjawab pertanyaan tersebut atau yang sejenisnya. Untuk membuka pandangan mengenai desentralisasi dalam Islam, artikel ini mengkaji desentralisasi sebagaimana diisyaratkan dalam ajaran Islam dan diterapkan dalam pemerintahan Dinasti 'U māniyyah dan Indonesia. Tujuannya adalah untuk membangun fondasi bagi kebijakan desentralisasi sesuai dengan ajaran Islam agar mampu memberikan kontribusi bagi pengembangan kebijakan yang lebih baik dalam konteks Indonesia maupun dunia internasional.

\section{Pembahasan}

Akar pemikiran desentralisasi dapat dirujuk pada isyarat Nabi Saw dalam pesannya kepada Mu'ā ibn Jabal saat akan diutus ke Yaman. Dalam hadits yang terkenal tersebut, Mu'ā ibn Jabal menyebutkan penggunaan Alquran, Sunnah, dan akal dalam proses penyelesaian masalah yang

14 Abdurrahman Atçil, "Decentralization, Imperialism, and Ottoman Sovereignty in the Arab Lands Before 1914: Shakib Arslan's Polemic Against the Decentralization Party, Welt des Islams, Vol. 52, Issue 3-4, 2012, hal. 26-49.

${ }^{15}$ Ibid. akan dihadapi ketika menghadapi masyarakat tanpa Nabi Saw sebagai salah satu sumber hukum. ${ }^{16}$ Hal yang kurang lebih sama juga dapat dirujuk pada kebiasaan Abū Bakr dalam pola pengambilan keputusan yang dimulai dari menelusuri ajaran Islam dalam Alquran, dilanjutkan dengan Sunnah Nabi Saw. Sekiranya dari kedua sumber tersebut tidak ditemui ketentuan yang diharapkan, maka tokoh-tokoh terbaik dimintai pendapat sampai pada satu kesimpulan yang selanjutnya dipakai sebagai sumber hukum. ${ }^{17}$ 'Umar ibn Al-Kha āb juga memberikan pesan kepada Syuray ketika diutus menjadi qa $\overline{1}$ di Kūfah untuk menggunakan Alquran dan Hadits sebagai sumber rujukan dalam mengambil keputusan. Jika dari kedua sumber tersebut tidak ditemukan solusi, barulah ijtihad digunakan. ${ }^{18}$ Kejadian-kejadian di atas bagi para ahli U ul menjadi dasar bagi penggunaan Ijmā' dan Qiyās sebagai sumber hukum. ${ }^{19} \mathrm{Hal}$ ini sekaligus menjadi petunjuk adanya peluang bagi pengembangan sebuah model pemerintahan desentralisasi dengan merujuk pada penggunaan kesepakatan kolektif dan ijtihad dalam menghadapi masalah modern.

Celah lain untuk pengembangan model desentralisasi juga dapat dirujuk pada pola penarikan kharāj atau pajak tanah pada masa penaklukan Islam. Para pemimpin pasukan Islam biasanya berhati-hati dalam menetapkan pajak atas tanah terhadap penduduk di daerah yang ditaklukkan. Tugas

${ }^{16}$ Riwayat hadits ini antara lain dapat dirujuk dari Abū Dāwud dan At-Timi 1 melalui Al- āri dari Ibn 'Umar dan sejumlah orang ahli am sahabat Mu'ā ibn Jabal. Lihat Jamāl ad-Dīn Abū Mu ammad 'Abd Allāh ibn Yūsuf Az-Zayla'ī Al- anafī, $N a b$ arRāyah li A ādi al-Hidāyah, dita qīq oleh Mu ammad 'Awāmah, (Jeddah: Dār a - aqafāah alIslāmiyyah, 1997), juz 4, hal. 63.

17 Wahbah Az-Zuhaylī, U ul Al-Fiqh AlIslāmī, Edisi Pertama, (Damaskus: Dār Al-Fikr, 1986), juz 1, hal. 419.

${ }^{18}$ Mannā' Al-Qa ān, Tārīkh At-Tasyrī' AlIslāmī, Cetakan Kelima, (Kairo: Maktabah Wahbah, 2001), hal. 231.

${ }^{19}$ Khālid Rama ān asan, Mu jajam Ușul AlFiqh, Cetakan Pertama, (Ban̄̄ Yūsuf, Mesir: ArRau ah, 1998), hal. 25 dan 227. 
memungut pajak tersebut bahkan biasanya diserahkan kepada penguasa setempat yang memiliki kompetensi untuk mengurus birokrasi pemerintahan sebelumnya. Bagi pemimpin pasukan Islam, pengakuan akan wilayah tersebut pada kekuasaan Islamlah yang dipentingkan sehingga bagi masyarakat yang ditaklukkan tidak terdapat perubahan penting dalam pembayaran kewajiban atas tanah karena yang terjadi hanyalah perubahan kepada siapa peruntukkan pajak tersebut. Atas dasar hal ini, maka sistem fiskal Islam mengalami perbedaan antara satu daerah dengan daerah lainnya sesuai dengan perbedaan geografis. $^{20}$ Praktek dalam pemungutan sumber pendapatan negara semacam ini menunjukkan adanya peluang bagi perbedaan pola di masing-masing wilayah dengan memperhatikan kondisi masyarakat lokal.

Pengalaman penggunaan dīnār sebagai mata uang dalam negara Islam juga dapat dijadikan gambaran mengenai corak desentralisasi kebijakan terutama di bidang ekonomi. Dīnār disebutkan dalam Alquran yaitu dalam Āli Imrān [3] ayat 75 sebagai alat transaksi yang berlaku umum termasuk dalam hubungan dengan umat lain dalam hal ini bangsa Yahudi. Masyarakat Arab sebelum Islam datang telah mengenal dan menggunakan dīnār baik yang berasal dari Romawi maupun Persia. Dīnār bercorak Arab pertama kali muncul tanpa tahun tapi kemungkinan besar berasal dari 72 H/691-2 M di Damaskus di masa pemerintahan Dinasi Umayyah. Bentuknya menyerupai koin yang dibuat oleh Heraklius dan dua anaknya dengan perubahan pada simbol Kriten yang dihapus, dan ditambah dengan simbol-simbol Arab. ${ }^{21}$

Pada perkembangan selanjutnya, model dīnār yang lebih mencerminkan sifat Arab muncul dengan gambar khalifah

20 Cl. Cahen, "Kharādj", dalam E. van Donzel, B. Lewis, dan Ch. Pellat (eds.), The Encyclopedia of Islam New Edition, (Leiden: E.J. Brill, 1997), Volume IV, hal. 1030.

${ }^{21}$ G.C. Miles, "Dīnār", dalam B. Lewis, Ch. Pellat, dan J. Schacht (eds.), The Encyclopedia of Islam New Edition, (Leiden: E.J. Brill, 1991), Volume II, hal. 297. memegang pedang pada $74 \mathrm{H} / 693-4 \mathrm{M}$ di Damaskus. Dīnār jenis ini juga diproduksi kembali pada tahun 76 dan $77 \mathrm{H}^{22}$ Dīnār khusus dengan tulisan Bahasa Arab bermakna "Muhammad Utusan Allah" juga pernah muncul di masa "Abd Allah ibn Zubayr memerintah di wilayah ijaz sebelum ia akhirnya dikalahkan Abd alMalik ibn Marwān. ${ }^{23}$ Abd al-Malik ibn Marwān kemudian melakukan salah satu upaya bersejarah untuk menyeragamkan mata uang dengan memperkenalkan dīnār bergambar dirinya dan menggunakan dīnār secara resmi sebagai pengganti mata uang lainnya yang memiliki simbol atau kata-kata bukan dari tradisi Islam. ${ }^{24}$ Reformasi dīnār ini terus berlanjut hingga kekuasaan Dinasti Umayyah berakhir. $^{25}$

Pada masa selanjutnya yaitu Dinasti 'Abbasiyyah, terutama sebelum Al-Ma'mūn berkuasa mata uang di masing-masing wilayah terkadang mencakup tidak hanya nama khalifah tetapi juga nama gubernur wilayah tersebut maupun para pejabatnya. Perkembangan semacam ini selanjutnya disikapi Al-Ma'mūn dengan sentralisasi mata uang dīnār dan dirhām serta penghapusan nama baik dirinya maupun pimpinan wilayah lainnya. Mata uang baru ini hanya mengandalkan tampilan artistik dalam kha Kūfī sebagai simbol persatuan Dinasti 'Abbasiyyah di masa kekuasaan Al-Ma'mūn. Perubahan ini dimaksudkan untuk menata ulang sistem perpajakan dan penghitungan hasil pertanian. ${ }^{26}$ Beragamnya mata uang

${ }^{22}$ Ibid.

${ }^{23}$ Chase F. Robinson, "The Rise of Islam, 600-705", dalam Chase F. Robinson (ed.), The New Cambridge History of Islam, Volume I The Formation of the Islamic World: Sixth to Eleventh Centuries, (Cambridge: Cambridge University Press, 2011), hal. 217.

${ }^{24}$ Chase F. Robinson, "The Rise of Islam, 600-705", hal. 220.

${ }^{25}$ Andrew S. Ehrenkreutz, "Studies in the Monetary History of the Near East in the Middle Ages: The Standard of Fineness of Some Types of Dinars", Journal of the Economic and Social History of the Orient, Vol. 2, No. 2 (May, 1959), hal. 128-161.

${ }^{26}$ Tayeb Al-Hibri, "The Empire in Iraq, 763861" dalam Chase F. Robinson (ed.), The New Cambridge History of Islam, Volume I The Formation 
yang digunakan di berbagai wilayah Islam sebagaimana dijelaskan di atas menunjukkan adanya kecenderungan beragamnya kebijakan ekonomi dalam ajaran Islam. Beragam kondisi di masing-masing wilayah memberikan ruang bagi digunakannya kebijakan yang beragam pula sesuai dengan kebutuhan di tingkat wilayah.

\section{Pengalaman Desentralisasi Dinasti 'Uśmāniyyah}

Penerapan desentralisasi dalam kehidupan politik dan ekonomi Dinasti 'U māniyyah terjadi terutama pada abad ke16 sampai dengan akhir abad ke-18 M. Pada masa ini Dinasti ' $U$ māniyyah mencapai puncak kejayaan di bawah kepemimpinan Bayezid II (1481-1512), Selim I (15121520), dan Süleyman I the Magnificent $(1520-66) .^{27}$ Pada masa ini pula struktur klasik masyarakat terbentuk dengan dua kelompok utama yaitu kelompok penguasa (rulling class) dan rakyat (subject class). Kelompok pertama ini diisi oleh mereka yang menyatakan kesetiaan kepada Dinasti 'U māniyyah, memeluk Islam, menggunakan jalan hidup Dinasti 'U māniyyah (Ottoman Way), dan memiliki satu kekhususan bidang yang diperlukan dalam mengelola urusan kenegaraan. $^{28}$

Kelompok penguasa mencakup lingkaran dalam atau inner service (enderun) keluarga sultan dan juga lingkaran luar atau outer service (birun). Lingkaran luar mencakup (1) The Scribal Institution atau Kesekretariatan (kalemiye) yang mengurusi

of the Islamic World: Sixth to Eleventh Centuries, (Cambridge: Cambridge University Press, 2011), hal. 288 dan Tayeb El-Hibri, "Coinage Reform under the Abbāsid Caliph al-Ma mūn", Journal of the Economic and Social History of the Orient, Vol. 36, No. 1 (1993), hal.58-83.

27 Encyclopædia Britannica, "Ottoman Reference Suite, (Chicago: Encyclopædia Britannica, 2012).

${ }^{28}$ Stanford J. Shaw dan Gökhan Çetinsaya, "Ottoman Empire", The Oxford Encyclopedia of the Islamic World, Oxford Islamic Studies Online, diakses dari

http://www.oxfordislamicstudies.com/article/opr/t236/ e0611 pada 3 Mei 2011. perbendaharaan negara dengan anggota para pencatat (ehl-i kalem), perdana menteri (sadr-i azam), para menteri di bawahnya (pasa) dan dewan istana (divan); (2) The Military Institution atau Kemiliteran (seyfiye) yang mengurusi masalah militer dan keamanan dengan bagian-bagian seperti prajurit perang (ehl-i seyf), pasukan berkuda (sipahi), pasukan infanteri (yeniçeri), dan pasukan bersenjata berat (devşirme); dan (3) the Religious or Cultural Institution atau Keagamaan dan Budaya (ilmiye) yang dipimpin oleh şeyhülislam atau shaykh alIslām dalam Bahasa Arab dengan anggota berupa majelis ulama (ehl-i ilm, ülemâ), imam masjid (imām), hakim (qadi) dan pakar hukum (müfti). ${ }^{29}$

Sedangkan kelompok rakyat dibagi berdasarkan agama dan pekerjaan. Millet atau taife atau cemaat merupakan pembagian kelompok berdasarkan agama dengan hak otonom untuk mengatur diri sendiri menurut adat kebiasaan dan hukum yang mereka gunakan. Pimpinan millet memiliki tanggung jawab untuk memastikan anggotanya memenuhi kewajiban terhadap negara terutama berkaitan dengan pajak. Selain itu, rakyat juga dibagi berdasarkan fungsi ekonomisnya dalam bentuk guilds. Guilds inilah yang mengatur aktivitas ekonomi seperti penentuan standar yang diikuti anggotanya dan dapat diisi oleh beragam latar belakang masyarakat dengan tujuan ekonomi dan sosial yang sama. Organisasi lain yang penting dalam konteks pendapatan negara adalah mukâ $a$ a, yaitu sistem yang memberikan kelompok penguasa kekuasaan untuk mengatur sejumlah tertentu wilayah dan memungut pajak dari wilayah tersebut. Pajak yang dikumpulkan selanjutnya dapat didistribusikan kepada sultan selaku penguasa pusat maupun diambil sebagian sebagai pendapatan kelompok penguasa. Terdapat tiga jenis mukâ a a yang terkenal yaitu timar, emanet, dan iltizām. ${ }^{30}$

29 Encyclopædia Britannica, "Ottoman Empire" dan Stanford J. Shaw dan Gökhan Çetinsaya, "Ottoman Empire".

${ }^{30}$ Ibid. 
Timar sebagai salah satu sistem dalam mukâ a a memiliki peran besar dalam membentuk ciri khas desentralisasi dalam Dinasti 'U māniyyah. Melalui timar, pajak dikumpulkan dan didistribusikan sebagai pendapatan dalam konteks lokal. Meskipun terdapat bagian yang didistribusikan ke pemerintah pusat, jumlahnya relatif kecil jika dibandingkan dengan bagian yang dihabiskan di tingkat lokal. $^{31}$ Pola lain dalam desentralisasi juga ditemui terkait kebijakan mata uang Dinasti ' $U$ māniyyah. Pemerintahan Dinasti 'U māniyyah tidak selalu mampu memenuhi kebutuhan mata uang untuk sirkulasi kegiatan ekonominya dan kebutuhan tersebut adakalanya dipenuhi oleh mata uang Eropa. Pada perkembangan selanjutnya, mata uang Eropa bahkan menjadi dominan di sejumlah wilayah kekuasaan Dinasti 'U māniyyah seperti wilayah Balkan, Istambul, Asia Kecil, hingga Suriah. Penggunaan koin Eropa juga tercatat dalam putusan-putusan pengadilan di tingkat lokal. $^{32}$

Praktek desentralisasi khusus juga layak disebutkan sebagaimana yang terjadi dalam hubungan antara pemerintah pusat Dinasti ' $U$ māniyyah dan wilayah Krimea (Ukraina) di bawahnya. Wilayah ini menjadi contoh bagaimana aplikasi hukum Islam terutama berkaitan dengan aspek ekonomi dapat mengalami perubahan sesuai tuntutan yang ada. Karena merupakan penghasil anggur berkualitas, maka salah satu sumber pendapatan pemerintah Dinasti ' $U$ māniyyah dari wilayah ini adalah pajak anggur. Penerapan pajak anggur ini bahkan juga diikuti oleh sejumlah investasi oleh penduduk muslim untuk usaha di bidang pertanian anggur. ${ }^{33}$ Mengingat anggur

${ }^{31}$ Sevket Pamuk, A Monetary History of the Ottoman Empire, (Cambridge: Cambridge University Press, 2000), hal. 10 dan 85. $146-147$

${ }^{32}$ Sevket Pamuk, A Monetary History..., hal.

${ }^{33}$ Alan Fisher, "The Ottoman Crimea in the Sixteenth Century", Harvard Ukrainian Studies, Vol. 5, No. 2 (June 1981), hal. 135-170 dan Oleksander Halenko, "Wine Production, Marketing and Consumption in the Ottoman Crimea, 1520-1542”, merupakan minuman memabukkan yang dilarang dalam Islam, sebagaimana disebutkan secara tegas dalam Alquran Surat Al-Baqarah [2] ayat 219 dan Al-Māidah [5] ayat 90-91, maka pemungutan pajak terhadapnya merupakan pengecualian kebijakan yang menandakan adanya pola desentralisasi dalam politik ekonomi Dinasti 'U māniyyah.

Gambaran di atas menunjukkan bahwa dalam perjalanan sejarah Dinasti 'U māniyyah telah mempraktekkan desentralisasi dengan beragam tingkatnya. Pemisahan kekuasaan pada sejumlah wilayah yang dipimpin kelompok penguasa terutama dari pihak militer menjadi corak utama yang membuat desentralisasi berjalan. Dalam konteks ini, perlu diingat bahwa luasnya wilayah yang dikuasai menjadi salah satu alasan mengapa desentralisasi menjadi penting. Selain itu, posisi pimpinan militer di masing-masing wilayah juga penting untuk diperhatikan karena jasanya dalam memperluas wilayah sehingga desentralisasi dengan tambahan hak mengelola sumber pendapatan secara khusus menjadi tidak terhindarkan.

Sebagaimana negara dengan wilayah yang luas dan beragam bangsa di dalamnya, Dinasti ' $U$ māniyyah juga mengalami kemunduran. Kemunduran pada masa setelah Süleyman I the Magnificent terutama sekali dikaitkan dengan kebijakan desentralisasi, selain masalah lain. Desentralisasi sebagai konsekuensi logis kebutuhan pemerintah pusat terhadap loyalitas pimpinan militer ikut meningkatkan dominasi pasukan bersenjata di banyak aspek kehidupan. Dominasi ini pada akhirnya berdampak pada makin kuatnya posisi militer dan mengurangi kekuasaan sultan. ${ }^{34}$ Dampak selanjutnya terwujud dalam korupsi dan nepotisme yang tumbuh subur akibat lemahnya kekuasaan sultan dalam mengendalikan militer sehingga mereka dapat memainkan peran politik di

Journal of the Economic and Social History of the Orient, Vol. 47, No. 4 (2004), hal. 507-547.

34 Encyclopædia Britannica, "Ottoman Empire..." dan Stanford J. Shaw dan Gökhan Çetinsaya, "Ottoman Empire...". 
pemerintahan untuk keuntungan pribadi dan kelompok. ${ }^{35}$ Masalah ekonomi yang terutama berasal dari dampak perdagangan internasional juga ikut menambah kemunduran di masa ini mengingat industri dalam negeri di bawah guilds gagal bersaing dengan produk Eropa yang lebih murah dan kualitas lebih baik. ${ }^{36}$

\section{Pengalaman Desentralisasi Orde Baru Indonesia}

Desentralisasi di Indonesia mulai dikenal dengan diundangkannya UU No. 5 Tahun 1974 yang ditujukan untuk "membangun otonomi daerah yang benarbenar nyata dan bertanggung jawab". ${ }^{37}$ Hal ini wajar mengingat untuk negara dengan wilayah sedemikian luas, pemerintah pusat yang kuat dan desentralisasi secara bersamasama merupakan kebutuhan untuk menjamin tercapainya tujuan pembangunan. ${ }^{38}$ Bentuk desentralisasi ini kemudian diwujudkan dalam struktur pemerintahan di bawah pemerintah pusat yaitu provinsi, kabupate, kecamatan dan desa. Meskipun dimaksudkan untuk memberikan peluang bagi peningkatan peran daerah dalam pemerintahan dan ekonomi, kebutuhan akan stabilitas menjadikan proses politik yang berlangsung di daerah masih tetap dalam koridor pemerintah pusat. Sebagai ilustrasi, jabatan gubernur, sebagai pimpinan di tingkat provinsi, pada tahun 198327 provinsi sebanyak 21 diantaranya diisi oleh pejabat berlatar belakang militer. Di tingkat kabupaten, atau setingkat di bawah provinsi,

35 Encyclopædia Britannica, "Ottoman Empire", Stanford J. Shaw dan Gökhan Çetinsaya, "Ottoman Empire" dan Ebru Boyar dan Kate Fleet, A Social History of Ottoman Istanbul, (Cambridge: Cambridge University Press, 2010), hal. 105.

Empire..."

36 Encyclopædia Britannica, "Ottoman

${ }^{37}$ Nick Devas, Financing Local Government in Indonesia, (Athens, Ohio: Center for International Studies, 1989), hal. 37.

38 Simon Kuznets, Modern Economic Growth: Rate, Structure and Spread, (New Haven dan London: Yale University Press, 1966).
$40 \%$ bupatinya juga merupakan pensiunan tentara. ${ }^{39}$

Terkait dana dalam rangka pembangunan, pemerintah di tingkat lokal memiliki sejumlah sumber yang berasal dari daerah dengan beragam bentuknya, terutama pajak properti sebagai sumber pendapatan utama. Pajak lainnya yang dikenal adalah pajak kendaraan bermotor dan pajak hiburan (keduanya diambil pemerintah daerah tingkat I atau provinsi), pajak hotel dan restoran, pajak penerangan jalan, pajak pencatatan usaha, pajak iklan, pajak pengolahan daging, pajak terhadap orang asing, pajak radio, dan pajak lainnya. ${ }^{40}$ Perlakuan khusus terkait sumber pendapatan juga terjadi dalam konteks Indonesia dalam bentuk legalisasi judi yang menjadi sumber pendapatan cukup signifikan. Legalisasi perjudian memang pada akhirnya diakhiri seiring sejumlah protes dalam masyarakat, namun pernah menjadi sumber pendapatan penting di sejumlah kota besar, yaitu Jakarta, Palembang, Makassar, dan kota lainnya. ${ }^{41}$

Namun demikian, sumber dana dari daerah ini kebanyakan hanya mampu memenuhi seperempat kebutuhan pembangunan daerah. Sisanya dipenuhi oleh sumber dana yang berasal dari pemerintah pusat. Akibatnya, pemerintah daerah masih sangat tergantung pada pemerintah pusat sekaligus menunjukkan superioritas dalam pembangunan sebagai watak pemerintahan sentralistik. $^{42}$ Dengan demikian, meskipun bermaksud meningkatkan peran daerah melalui desentralisasi, praktek kebijakan pemerintahan Indonesia justru mengarah pada sentralisasi. Justifikasi atas praktek ini

39 Gustav Ranis dan Frances Stewart, "Decentralisation in Indonesia", Bulletin of Indonesian Economic Studies, Vol. 30, No. 3, December 1994, hal. 41-72.

${ }^{40}$ Nick Devas, "Local Taxation in Indonesia: Opportunities for Reform", Bulletin of Indonesian Economic Studies, Vol. 24, No. 2, August 1988, hal. 58-85.

${ }^{41}$ T.M. Smith dan R.S. Smith, "Municipal Finance", Bulletin of Indonesian Economic Studies, Vol. 7, No. 1, 1971, hal. 114-130.

42 Gustav Ranis dan Frances Stewart, "Decentralisation in Indonesia". 
antara lain demi menjaga persatuan bangsa sekaligus mengantisipasi upaya penjajahan Belanda yang sebelumnya mengarahkan model pemerintahan federalisme di Indonesia. ${ }^{43}$ Apakah sentralisasi kemudian dibenci? Dalam konteks Indonesia masa Orde Baru, sentralisasi juga diikuti dengan pertumbuhan ekonomi jangka panjang yang terjaga, stabilitas politik dan mesin partai penguasa yang bekerja dengan baik. Hal ini berimbas pada makin tingginya kepercayaan rakyat terhadap pemerintah, meskipun kebijakan ekonomi yang diambil tidak selalu sesuai dengan tujuan awal pembangunan. ${ }^{44}$

Sebagaimana

pengalaman desentralisasi pada Dinasti 'U māniyyah, Indonesia di masa Orde Baru juga memiliki penyakit akut bernama korupsi, kolusi, dan nepotisme (KKN). Penyakit-penyakit semacam ini secara logis muncul sebagai konsekuensi pemusatan kekuasaan melalui dominasi militer dalam politik Orde Baru. Ketiga penyakit pemerintahan ini kemudian menjadi awal bagi berakhirnya rezim Orde Baru yang ditandai dengan Reformasi. Perubahan yang terjadi pada masa ini terutama sekali ditandai dengan bergantinya rezim desentralisasi semu yang menjurus ke sentralisasi menjadi bentuk baru desentralisasi melalui sejumlah perundangan terutama melalui UU No. 22 Tahun 1999 tentang Pemerintah Daerah dan UU No. 25 Tahun 1999 tentang Perimbangan Keuangan Pusat dan Daerah. ${ }^{45}$

Namun demikian, meskipun dimaksudkan untuk mengatasi korupsi, kolusi, dan nepotisme, Reformasi sejatinya masih belum sepenuhnya mampu mengatasi masalah krusial tersebut. Jika dihitung dari indikator tata pemerintahan yang baik misalnya, Reformasi lebih baik dari Orde

${ }^{43}$ James Alm, Robert H. Aten, dan Roy Bahl, "Can Indonesia Decentralise Successfully? Plans, Problems and Prospects", Bulletin of Indonesian Economic Studies, Vol. 37, No. 1, 2001, hal. 83-102.

${ }^{44}$ R. William Liddle, "Indonesia in 1987: The New Order at the Height of Its Power", Asian Survey, Vol. 28, No. 2, A Survey of Asia in 1987: Part II (Feb., 1988), hal. 180-191.

${ }^{45}$ James Alm, Robert H. Aten, dan Roy Bahl, "Can Indonesia Decentralise Successfully?..."
Baru dalam hal kebebasan berbicara dan akuntabilitas (voice and accountability), stabilitas politik dan ketiadaan konflik (political stability and absence of violence), dan efektifitas pemerintahan (government effectiveness). Sedangkan pada aspek lainnya seperti kualitas perundangan (regulatory quality), penegakkan hukum (rule of law), dan pengendalian korupsi (control of corruption) Reformasi tidak lebih baik dibandingkan Orde Baru. ${ }^{46}$

\section{Menuju Model Desentralisasi dalam Islam}

Penjelasan di atas menunjukkan bahwa kebijakan desentralisasi memiliki ruang dalam ajaran Islam sebagaimana dirujuk pada sejumlah hadits dan a ar sahabat. Desentralisasi juga memiliki fondasi dalam perjalanan sejarah umat Islam karena dipraktekkan oleh Dinasti 'U māniyyah yang merupakan simbol terakhir kekuasaan pemerintahan Islam. Pengalaman menjalankan desentralisasinya juga ditemui dalam kehidupan politik dan ekonomi di Indonesia yang saat ini menjadi negara demokratis terbesar ketiga dunia dan negara dengan penduduk muslim terbesar di dunia. Baik dalam pengalaman Dinasti 'U māniyyah maupun Indonesia, praktek desentralisasi terbukti tidak dengan serta merta menyelesaikan semua masalah mengingat dalam perkembangan terdapat sejumlah dinamika.

Praktek desentralisasi di kedua contoh di atas mampu memberikan dampak positif berupa terjaganya kesatuan bangsa sebagai modal utama dalam pembangunan meskipun diiringi dengan dominasi pemerintah pusat dalam bentuk kekuatan militer di posisi pemerintahan. Stabilitas politik ini juga diakui sebagai salah satu unsur penting sebuah negara dalam ajaran Islam. Selain itu, negara dalam Islam juga memiliki sejumlah tujuan sosial ekonomi yaitu menegakkan keadilan atau persamaan, pembagian kesejahteraan dalam masyarakat,

46 World Bank, Worldwide Governance Indicators, diakses dari http://info.worldbank.org/governance/wgi/index.aspx\# home pada 4 Mei 2013. 
meningkatkan pertumbuhan ekonomi, dan meningkatkan budaya dalam masyarakat. ${ }^{47}$ Tanggung jawab lain yang diemban sebuah negara mencakup jaminan terpenuhinya kebutuhan minimal rakyat baik pria maupun wanita yang tinggal di wilayah negara tersebut dan pengurangan ketimpangan pendapatan dan kesejahteraan antara penduduknya. $^{48}$

Untuk itulah, pemerintah dalam sebuah negara dengan sistem Islam dituntut mampu menjaga stabilitas sekaligus meningkatkan kualitas kehidupan rakyatnya. Demi mencapai tujuan tersebut, pemerintah pusat dalam negara Islam terutama sekali berkepentingan untuk menggunakan pendapatan negara untuk sejumlah pengeluaran terutama dalam hal-hal berikut:

1) Pertahanan dan keamanan negara sebagai perwujudan kedaulatan negara. Menjaga pertahanan dan keamanan dilakukan baik terhadap potensi kekerasan dari dalam maupun ancaman dari luar negeri. ${ }^{49}$ Pengeluaran militer menduduki peran yang sangat penting dalam perkembangan awal Islam karena menjadi penyangga negara yang baru saja muncul. Sejumlah lembaga bahkan muncul sebagai konsekuensi dari pentingnya peranan militer ini.

2) Administrasi pemerintahan yang meliputi gaji para gubernur, menteri, dan pejabat pemerintahan. Pengeluaran administrasi pemerintahan ini mutlak diperlukan untuk menjamin keberlangsungan tugas-tugas negara. ${ }^{50}$

${ }^{47}$ F.R. Faridi, "Theory of Fiscal Policy in an Islamic State", Journal of Research in Islamic Economics, Vol. 1, No. 1 (1403/1983), hlm. 15-30.

48 Muhammad Nejatullah Siddiqi, Some Aspects of the Islamic Economy, (Lahore, Pakistan: Islamic Publication, Ltd., 1970), hal. 128-129 dan Abidin Ahmad Salama, "Fiscal Policy of an Islamic State", hal. 54.

${ }^{49}$ S. A. Siddiqi, Public Finance in Islam, (New Delhi, India: Adam Publishers \& Distributors, 1982), hal. 170 .

50 Abidin Ahmad Salama, "Fiscal Policy of an Islamic State", dalam Muhammoud A. Gulaid dan Mohamed Aden Abdulla, Readings in Public Finance
3) Pengadilan yang meliputi biaya peradilan, hakim, dan pejabat yang bertanggungjawab dalam proses pengambilan keputusan kehakiman. ${ }^{51}$

4) Pendidikan yang mencakup biaya penyediaan tempat pendidikan maupun pendidiknya. ${ }^{52}$

5) Penyediaan dan penjagaan fasilitas umum seperti infrastruktur jalan, jembatan, pelabuhan, dan sebagainya yang menjadi prasyarat bagi keberlangsungan kehidupan ekonomi dalam suatu negara. ${ }^{53}$

Penggunaan pendapatan negara untuk pengeluaran utama tersebut mengindikasikan pentingnya doktrin pemerintahan yang kuat dalam Islam. Namun demikian, mengingat kecenderungan pemusatan kekuatan dalam kerangka sentralisasi terbukti gagal menjaga stabilitas dan meningkatkan kesejahteraan jangka panjang, maka artikel ini juga mengarahkan pada pendekatan yang lebih terdesentralisasi dalam rangka mengelola pendapatan dan pengeluaran negara. Berdasarkan pengalaman Dinasti 'U māniyyah dan Indonesia di atas, terdapat sejumlah rekomendasi mengenai desentralisasi yang sebaiknya digunakan dalam konteks politik ekonomi Islam, yaitu:

1) Tugas yang dibebankan kepada pemerintahan di level daerah adalah tugas diluar keamanan, administrasi pemerintahan, kehakiman, pendidikan, dan penyediaan fasilitas umum. Tugas-tugas ini sebaiknya tetap dipegang oleh pemerintah pusat, sedangkan tugas-tugas yang berkaitan dengan pengembangan kebudayaan, pengurangan kemiskinan dan pengangguran, peningkatan partisipasi publik, dan tugas lain yang berkaitan dengan masyarakat di

in Islam, (Jeddah, Saudi Arabia: Islamic Development Bank, Islamic Research and Training Institute, 1415 H/ 1995 M), hal. 51 dan Muhammad, Kebijakan Fiskal dan Moneter, ibid.

51 Abidin Ahmad Salama, "Fiscal Policy of an Islamic State", ibid. dan Muhammad, Kebijakan Fiskal dan Moneter, ibid.

$$
\begin{aligned}
& 52 \text { ibid. } \\
& 53 \text { ibid. }
\end{aligned}
$$


tingkat lokal sebaiknya dilimpahkan ke pemerintah di daerah;

2) Afiliasi pimpinan daerah dengan militer sebaiknya dikurangi secara bertahap sembari diiringi dengan peningkatan kapasitas masyarakat sipil dalam mengelola pemerintahan yang bersih. Kepemimpinan militer yang selama ini terjadi meskipun memiliki potensi pada stabilitas, cenderung mengurangi potensi dan inisiatif lokal yang sangat penting bagi pembangunan bangsa;

3) Penggunaan mata uang dalam konteks ekonomi daerah memiliki peluang untuk tidak selalu tergantung pada mata uang yang disahkan pemerintah pusat mengingat kompleksitas ekonomi di wilayah. Daerah perbatasan yang mengalami tekanan ekonomi akibat penggunaan mata uang resmi pemerintah pusat misalnya dapat menggunakan mata uang yang lebih stabil. Dalam konteks Indonesia, hal ini bisa dirumuskan dengan legalisasi penggunaan Ringgit Malaysia di perbatasan dengan Malaysia mengingat superioritas mata uang tersebut terhadap Rupiah Indonesia. Jika dipaksakan menggunakan Rupiah Indonesia, masyarakat di perbatasan justru akan selalu mengalami kerugian akibat lemahnya mata uang lokal, padahal transaksi sehari-hari mereka dilakukan dengan negara tetangga.

4) Posisi ahli agama Islam atau ulama yang independen juga menjadi penting dalam konteks desentralisasi karena melalui pemikiran mereka inilah nilai-nilai Islam dalam konteks lokal dapat dijaga dan diterapkan. Ulama dalam konteks ini dapat difungsikan sebagai dewan pengawas syariah yang lebih dahulu ada dalam lembaga keuangan. Peranan semacam ini penting untuk dilakukan sebagai alternatif kontrol dalam proses pengambilan keputusan politik yang terbukti sulit mengatasi korupsi, kolusi, dan nepotisme jika sematamata diserahkan melalui mekanisme demokrasi.

\section{Penutup}

Paparan di atas menunjukkan bahwa Islam secara umum lebih menghendaki politik yang terpusat demi mencapai tujuantujuan bernegara. Namun demikian, mengingat kompleksitas masalah yang selalu dialami umat manusia, sejak awal ajaran Islam juga memberi ruang untuk ijtihad dan pengambilan keputusan berbasis kesepakatan yang menjadi celah bagi masuknya sistem politik yang lebih terdesentralisasi. Peluang desentralisasi juga secara historis dipraktekkan oleh kekuasaan Islam terakhir yaitu Dinasti ' $U$ māniyyah dan juga negara berpenduduk muslim terbesar di dunia yaitu Indonesia. Namun demikian, perlu pula ditegaskan bahwa pengalaman di kedua kasus tersebut menunjukkan masih banyaknya celah dalam implementasi desentralisasi terutama dominasi pemerintah pusat melalui jalur kekuasaan militer yang berimbas pada perilaku penguasa yang korup dan membawa kehancuran.

Untuk itulah, artikel ini menganjurkan alternatif tambahan untuk sebuah konsep desentralisasi dalam politik dan ekonomi Islam dengan membatasi tugas pemerintah pusat dan daerah secara lebih proporisonal, mengurangi ketergantungan terhadap militer, memberi kesempatan pelonggaran mata uang, dan memperkuat posisi ulama sebagai penjaga ketentuan syariah. Alternatif ini antara lain dimaksudkan untuk mengurangi sisi negatif yang selalu muncul dalam praktek desentralisasi, sekaligus mewujudkan tujuan ekonomi Islam yang bertumpu pada pertumbuhan dan pemerataan.

Artikel ini memiliki sejumlah keterbatasan mengingat cakupan kajian yang terbatas pada idealisme ajaran Islam terutama di masa awal Islam, dilanjutkan pembahasan pada Dinasti ' $U$ māniyyah dan Indonesia yang tentu saja belum mewakili karakter dinamis ajaran Islam maupun kehidupan 
umatnya. Karena itu, artikel ini merekomendasikan kajian lanjutan yang lebih luas dengan studi kasus pada masa kekuasaan Islam yang lebih beragam, terutama pada masa-masa dimana kekuasaan Islam tersebar luas dengan karakter penduduk yang beragam. Meskipun memiliki sejumlah kekurangan, sebagai kajian awal, artikel ini layak menjadi acuan bagi pengembangan lanjutan dalam bidang desentralisasi yang makin banyak dilakukan namun kontribusi Islam di dalamnya masih sangat terbatas.

\section{Daftar Pustaka}

“Sunan Ibn Mājah", Mausū'ah Al-Hadi AnNabaw̄̄, Al-I dār Ats-Tsān̄̄.

Al-Hibri, Tayeb. "The Empire in Iraq, 763861" dalam Chase F. Robinson (ed.), The New Cambridge History of Islam, Volume I The Formation of the Islamic World: Sixth to Eleventh Centuries. Cambridge: Cambridge University Press, 2011.

Alm, James, Aten, Robert H. dan Bahl, Roy. "Can Indonesia Decentralise Successfully? Plans, Problems and Prospects", Bulletin of Indonesian Economic Studies, Vol. 37, No. 1, 2001, hal. 83-102.

Al-Qa ān, Mannā'. Tārīkh At-Tasyrī' AlIslāmī, Cetakan Kelima, Kairo: Maktabah Wahbah, 2001.

Al-Qur ubī, Abū Abd Allāh Mu ammad ibn A mad ibn Abū Bakr. Al-Jāmi' li A kām Al-Qur'an wa Al-Mubīnu li mā ta amanahu min As-Sunnah wa $\bar{A} y$ Al-Furqān, Edisi Pertama, ditahqīq oleh 'Abd Allāh ibn Abd Al$\mathrm{Mu}$ sin At-Turkī dan $\mathrm{Mu}$ ammad Ri wān 'Arsūqī. Beirut: Al-Resalah Publishers, 2007.

Anjum, Ovamir. "al-A kām al-Sul ānīyah" dalam The [Oxford] Encyclopedia of Islam and Law, Oxford Islamic Studies Online, diakses dari http://www.oxfordislamicstudies.com /article/opr/t349/e0001 pada 4 Mei 2013.
Atçil, Abdurrahman. "Decentralization, Imperialism, and Ottoman Sovereignty in the Arab Lands Before 1914: Shakib Arslan's Polemic Against the Decentralization Party, Welt des Islams, Vol. 52, Issue 3-4, 2012, hal. 26-49.

Az-Zayla'ī Al- anafī, Jamāl ad-Dīn Abū $\mathrm{Mu}$ ammad 'Abd Allāh ibn Yūsuf. Na b ar-Rāyah li A ādi al-Hidāyah, dita qīq oleh $\mathrm{Mu}$ ammad 'Awāmah. Jeddah: Dār a - aqafāah alIslāmiyyah, 1997.

Az-Zuhaylī, Wahbah. U ul Al-Fiqh AlIslāmī, Edisi Pertama, Juz 1, Damaskus: Dār Al-Fikr, 1986.

Bahri, Syuhada. "Kepemimpinan Islam", dalam Buletin Al-Jazeera, Edisi 04/Th. 2/2010, diakses dari http://aljazeeraik2s.blogspot.com/2010/09/ke pemimpinan-islam.html 11 Maret 2011.

Boyar, Ebru dan Fleet, Kate. A Social History of Ottoman Istanbul. Cambridge: Cambridge University Press, 2010.

Brockelmann, C. "al-Māwardī, Abū 'l- asan Alī b. Mu ammad b. abīb," dalam C.E. Bosworth, E. van Donzel, B. Lewis, dan Ch. Pellat (eds.), The Encyclopedia of Islam New Edition, Volume VI, Leiden: E.J. Brill, 1991.

Cahen, Cl. "Kharādj", dalam E. van Donzel, B. Lewis, dan Ch. Pellat (eds.), The Encyclopedia of Islam New Edition, Volume IV. Leiden: E.J. Brill, 1997.

Cheema, G. Shabbir dan Rondinelli, Dennis A. "From Government Decentralization to Decentralized Governance", dalam G. Shabbir Cheema dan Dennis A. Rondinelli (eds.), Decentralizing Governance: Emerging Concepts and Practices. Washington, D.C.: Brookings Institution Press, 2007.

Devas, Nick. "Local Taxation in Indonesia: Opportunities for Reform", Bulletin of Indonesian Economic Studies, Vol. 24, No. 2, August 1988, hal. 58-85. 
Devas, Nick. Financing Local Government in Indonesia. Athens, Ohio: Center for International Studies, 1989.

Ehrenkreutz, Andrew S. "Studies in the Monetary History of the Near East in the Middle Ages: The Standard of Fineness of Some Types of Dinars", Journal of the Economic and Social History of the Orient, Vol. 2, No. 2 (May, 1959), hal. 128-161.

El-Hibri, Tayeb. "Coinage Reform under the Abbāsid Caliph al-Ma mūn”, Journal of the Economic and Social History of the Orient, Vol. 36, No. 1 (1993), hal.58-83.

Encyclopædia Britannica, "Māward̄̄, al-“, Encyclopadia Britannica Ultimate Reference Suite. Chicago: Encyclopædia Britannica, 2012.

Encyclopædia Britannica, "Ottoman Empire", Encyclopadia Britannica Ultimate Reference Suite. Chicago: Encyclopædia Britannica, 2012.

Faridi, F.R. "Theory of Fiscal Policy in an Islamic State", Journal of Research in Islamic Economics, Vol. 1, No. 1 (1403/1983), hlm. 15-30.

Fisher, Alan. "The Ottoman Crimea in the Sixteenth Century", Harvard Ukrainian Studies, Vol. 5, No. 2 (June 1981), hal. 135-170.

Halenko, Oleksander. "Wine Production, Marketing and Consumption in the Ottoman Crimea, 1520-1542", Journal of the Economic and Social History of the Orient, Vol. 47, No. 4 (2004), hal. 507-547.

asan, Khālid Rama ān. Mu'jam Ușul AlFiqh, Cetakan Pertama. Ban̄i Yūsuf, Mesir: Ar-Rau ah, 1998.

Kuznets, Simon. Modern Economic Growth: Rate, Structure and Spread. New Haven dan London: Yale University Press, 1966.

Liddle, R. William. "Indonesia in 1987: The New Order at the Height of Its Power", Asian Survey, Vol. 28, No. 2, A Survey of Asia in 1987: Part II (Feb., 1988), hal. 180-191.
Miles, G.C. "Dīnār", dalam B. Lewis, Ch. Pellat, dan J. Schacht (eds.), The Encyclopedia of Islam New Edition, Volume II. Leiden: E.J. Brill, 1991.

Pamuk, Sevket. A Monetary History of the Ottoman Empire. Cambridge: Cambridge University Press, 2000.

Ranis, Gustav dan Stewart, Frances. "Decentralisation in Indonesia", Bulletin of Indonesian Economic Studies, Vol. 30, No. 3, December 1994, hal. 41-72.

Robinson, Chase F. "The Rise of Islam, 600705", dalam Chase F. Robinson (ed.), The New Cambridge History of Islam, Volume I The Formation of the Islamic World: Sixth to Eleventh Centuries. Cambridge: Cambridge University Press, 2011.

Salama, Abidin Ahmad. "Fiscal Policy of an Islamic State", dalam Muhammoud A. Gulaid dan Mohamed Aden Abdulla, Readings in Public Finance in Islam. Jeddah, Saudi Arabia: Islamic Development Bank, Islamic Research and Training Institute, 1415 H/ 1995 M.

Shaw Stanford J. dan Çetinsaya, Gökhan. "Ottoman Empire", The Oxford Encyclopedia of the Islamic World, Oxford Islamic Studies Online, diakses dari http://www.oxfordislamicstudies.com /article/opr/t236/e0611 pada 3 Mei 2011.

Siddiqi, Muhammad Nejatullah. Some Aspects of the Islamic Economy. Lahore, Pakistan: Islamic Publication, Ltd., 1970.

Siddiqi, S. A. Public Finance in Islam. New Delhi, India: Adam Publishers \& Distributors, 1982.

Smith, T.M. dan Smith, R.S. "Municipal Finance", Bulletin of Indonesian Economic Studies, Vol. 7, No. 1, 1971, hal. 114-130.

Tanzi, Vito "Pitfalls on the Road to Fiscal Decentralization", dalam Ehtisham Ahmad dan Vito Tanzi, Managing 
Fiscal Decentralization. London, United Kingdom: Routledge, 2002.

Wellisch, Dietmar. Theory of Public Finance in a Federal State. Cambridge: Cambridge University Press, 2004.

World Bank. Worldwide Governance Indicators, diakses dari Edisi 2002. Semarang: Toha Putra, 2002. http://info.worldbank.org/governance/ wgi/index.aspx\#home pada 4 Mei 2013.

Yayasan Penyelenggara Penerjemah AlQur'an. Al-Qur'an Al-Karim dan Terjemahnya Departemen Agama RI 